\title{
ECONOMIC ASPECTS OF DRIED FRUIT PRODUCTION BY COMBINED TECHNOLOGY
}

\author{
Veljko Vukoje ${ }^{1}$, Ivan Pavkov ${ }^{2}$, Aleksandar Miljatović ${ }^{3}$ \\ *Corresponding authorE-mail:vukoje@polj.uns.ac.rs
}

\begin{abstract}
A R T I C LE IN F O
A B S T R A C T

Original Article

Received: 10 July 2018

Accepted: 07 September 2018

doi:10.5937/ekoPolj1803031V

UDC 338.515:[634.1/.8+663.952.031.1]

The aim of the paper is to evaluate the level of profitability of dried fruit production by combined technology (osmotic and convective). In the focus of the research is small capacity dryer - $500 \mathrm{~kg}$ of fresh fruit per day, which is used on agricultural holding. The costs of fresh fruit are the most important item in the structure of the price of all types of fruit $(67.1 \%$ on average), followed by labor

Keywords:

dried fruit, combined

technology, cost-effectiveness, economy costs $(14.0 \%)$ and packaging $(6.8 \%)$, while the share of energy is very modest $(2.74 \%)$. Comparative analysis shows that, individually, the most cost-effective is dried pears production. For 120 days of effective operation of the dryer, profit of $9,815 €$ is realized, with an acceptable JEL: Q12, Q13, Q16 degree of coefficient of economic efficiency (1.21). Investment in construction of drier $(31,900 €)$ is paid in 2.74 years. It is a profitable business, which can be a good source of income for agricultural holdings.
\end{abstract}

(C) 2018 EA. All rights reserved.

\section{Introduction}

The Republic of Serbia (RS) has very favorable conditions for the development of fruit production. In addition to quality soil and favorable climatic conditions, there are also very respectable human, technical, technological and market potentials for raising production and processing of fruit to a significantly higher level. However, despite visible shifts in recent years, the available potentials have not been sufficiently utilized. There are numerous reasons, from the unfavorable economic environment that has been present for several decades, to inadequate measures of agrarian policy in the field of investments and current subsidies. Raising new intensive fruit plantations, or processing capacities, require significant

1 Veljko Vukoje, Ph.D., Full Professor, University of Novi Sad, Faculty of Agriculture, Trg Dositeja Obradovića no. 8, 21000 Novi Sad, Serbia, Phone: +381 63 8367718, E-mail: vukoje@polj.uns.ac.rs, ORCID ID: 0000-0002-0801-9043

2 Ivan Pavkov, Ph.D., Associate Professor, University of Novi Sad, Faculty of Agriculture, Trg Dositeja Obradovića no. 8, 21000 Novi Sad, Serbia, Phone: +381 063557582, ivan. pavkov@polj.uns.ac.rs, ORCID ID: 0000-0002-6472-5209

3 Aleksandar Miljatović, BSc in argroeconomy, associate, University of Novi Sad, Faculty of Agriculture, Trg Dositeja Obradovića no. 8, 21000 Novi Sad, Serbia. aleksandar. miljatovic@polj.uns.ac.rs, ORCID ID: 0000-0002-3978-5832

http://ea.bg.ac.rs 
investment funds as well as current investments, which our traditional producers are not able to finance without well-organized institutional support. This support has been more serious in recent years, as seen through the raising of quality orchards, and more fruit processing plants.

Fruit production requires a significantly higher investment of all production factors than other branches of agriculture, especially human labor, whose availability may appear as a limiting factor. In addition, planting takes years to complete, so the risks are much higher (Lukač Bulatović et al., 2017).

An important precondition for increasing fruit production is the existence, growth and development of fruit processing capacities. Lukač Bulatović et al. (2012) points out that only about $10 \%$ of the total quantity of fruit produced is processed in Serbia. Observing the example of the United States, where up to $45 \%$ of the produced apples are processed, and as much as $70 \%$ of the produced plums, it can be said that fruit processing in the $\mathrm{RS}$ is at a low level. The fact is that the products of the higher technological level of processing carry a higher added value, that is, they provide higher profits. Therefore, it is necessary to pay more attention to all types of fruit processing, especially those that are less represented.

The processing of fresh fruit in Serbia is mainly focused on: freezing (rolend and block), juices, compotes, gelatinized products, marmalades and alcoholic beverages. In recent years, dried fruit has become very attractive, both in application in certain food forms and in scientific research. Drying of fruits, with the exception of plums, is at a low level in our country (Milić et al., 2006). The reasons are: lack of tradition, insufficient knowledge of technologies for drying other fruits, product unrecognizable to domestic customers, slow conquest of foreign markets, etc.

The development of new fruit drying technologies in the world is accompanied by certain economic results which affirm the fruit drying industry as a significant business sector. The Food and Agriculture Organization of the United Nations (FAO - OUN) suggests improving the fruit drying industry in all parts of the world. Considering the potential for fruit production in Serbia, the development of new drying technologies is of particular importance.

In the world, in 2017 , about 2.8 million tons of dry fruit was produced, which is $16 \%$ more than the average production in the period from 2008 to 2017 . The highest increase in production in the past decade was recorded in dry apricot production - as much as $40 \%$ compared to the 10-year average. The world's leading manufacturers are Turkey with 19\% of the world's total production and the US with 12\% (Source: www.nutfruit.org).

There is no precise data on the production and consumption of dry fruit in Serbia, but positive trends in recent years can be noticed. Dried fruits from imports are increasingly substituted with dry fruit from domestic production. The export of nuts and dried fruit from Serbia to the market of the countries of the European Union and other developed countries amounted to about 5.2 thousand tons in 2017, which is at the level of the ten-year average (2008-2017). Compared to the previous year, exports decreased by 3.7\%, but it increased 
by $16.4 \%$ compared to 2008 (Source: Authors' calculation based on data from Statistical Office of the Republic of Serbia - RZS).

Import of nuts and dried fruits in the RS in 2017 was about 500 tons, which is $15.4 \%$ more than in the previous year, but $11 \%$ less than in 2008. Observed in value, in 2017, nuts and dry fruits were imported by approximately 1.4 million US $\$$, an increase of $10.5 \%$ compared to the previous year, ie a decrease of $42.5 \%$ compared to 2008 (Source: Calculation of authors based on data from RZS).

It is clear that there are basic preconditions and significant space for increasing the production of dried fruit in RS. The subject of the research in this paper are the technological, organizational and economical aspects of dried fruit processing in Serbia. The research includes the following fruit varieties: apricot, peach, pear, apple, quince, raspberries and blueberries. The aim of the research is to determine the level of profitability of the production of dried fruit in driers with a capacity of up to $500 \mathrm{~kg}$ of fresh fruit per day.

\section{Materials and methods}

Research in this paper respects the real production, technological and economic conditions of business in Serbia. Economic calculations and analyzes are based on the laboratory established and in practice confirmed norms of material, labor and energy consumption. Experimental research has been carried out for a number of years in the Laboratory for Biosystem Engineering at the Faculty of Agriculture in Novi Sad, within the national Project TR31058. Original devices and technological methods for drying fruits with conventional (convective) and combined technology (osmotic and convective) have been developed. Dryers based on this technology have been successfully working in practice for many years.

The economic aspects of the production of dried fruit are considered continuously from 2010 within the mentioned project, which was published in several individual papers (Vukoje, Milić, 2011; Vukoje, Pavkov, 2010, 2015; Vukoje et al., 2010; $2011,2013 ; 2017)$. In this paper, the author take into account the corrections of the technological parameters that occurred in experimental research, with the integration of more production for the purposes of comparative analysis of cost-effectiveness and estimation of justification of investments in fruit drying plants (apricot, peach, pear, quince, apple, american blueberries and raspberries).

The survey relates to a small capacity plant that is suitable for production on family farm. In addition to the analysis of operating costs and outputs achieved in individual production, research also includes the cost-effectiveness of investment in raising fruit drying plants on agricultural holdings. The plant is used efficiently annually for 120 days, of which apricot dries for 20 days, peach and pear for 30 days, and apple, quince, raspberry and american blueberries for 10 days.

The drying capacity is $500 \mathrm{~kg}$ of fresh fruit per day, ie 60 tons for 120 of effective work. Fresh fruit is bought in the surrounding market, which means that it is not necessary 
to have refrigerator for fruit keeping. Calculations of costs and outcomes are based on real market prices at the end of 2017, ie the average exchange rate of the euro from the observed period ( $1 €=118 \mathrm{RSD}$ ). The results of the survey are expressed in euros to obtain a clearer picture and easier comparability of the data. The agricultural holding on which the production takes place is not in the VAT system.

The analysis of economic indicators is based primarily on analytical calculations of drying of certain types of fruit. Direct costs are primarily calculated for daily production, followed by calculations for the number of days of drying certain fruit types. In order to reliably estimate the cost-effectiveness of fruit drying, it is also necessary to determine additional indicators of success (cost-effectiveness and accumulation, income, return time of investment). In addition to the use of percentages and coefficients, a comparative analysis of the cost-effectiveness of individual production requires the reduction of the basic indicators of success in the unit of capacity, for which in this case it is most appropriate to take a "one drying working day", since the daily capacity is the same for all fruits (500 kg/day). The basic hypothesis of this research is: drying of the researched fruit species by the described technology in small driers with capacity up to $500 \mathrm{~kg}$ is profitable.

\section{Results and Discussion}

The results of research have showed that drying fruit with combined technology (osmotically and convectively) has significant advantages over conventional drying processes. The performed laboratory research showed that this technology, primarily due to osmotic drying, has a favorable effect on the preservation of the mechanical, visual and nutritional properties of this product (Babić et al., 2006). The combined drying technology has clearly separated drying stages: preparation of fresh fruit, osmotic drying, convective drying and packaging (Figure 1.). There are also certain specificities in the technological process for certain types of fruit, to which all phases of drying are not applied. This primarily refers to raspberries and blueberries, which do not pass the osmotic drying phase, which is explained in detail below.

Preparation of fruit for drying involves receiving and sorting of fruit according to the stage of maturity, dimensions, shape and color. Fresh fruit that does not meet the set criteria is separated and sent to other forms of processing (waste, Figure 1.). After washing, depending on the fruit type further steps follows. Apricot is cut into halves and the kernels are separated. The apricot kernel is broken and the soft part is extracted which represents an additional product. In peach, the fruit size determines the shape of the cut. The fruits are cut along the longitudinal fruit furrow, the kernel is separated, and the hemispheres are cut into four, six or eight parts (Pavkov, 2012). The fresh pear is cut along the longitudinal axis of the fruit, then the seeds are separated and depending on the size of the fresh fruit it is cut into four six or eight parts (the thickness of the slice up to $40 \mathrm{~mm}$ ) (Pavkov, 2012).

Preparation of quince and apple consists of peeling, separation of the seed house, then cutting to slices or cubes (Pavkov et al., 2008). For all fruits that are cut before drying, 
it is very important to get the maximally uniform parts. American blueberries and raspberries are dried in whole fruits shape (Pavkov et al., 2017).

Cut out fruit is a subject to rapid oxidation, or color change. In order to retain natural color, an antioxidant treatment is performed. Apricot, peach, pear and quince are exposed to sulfur dioxide in the sulfur storage chamber (Pavkov et al., 2009; 2011; Radojčin et al., 2010; 2015). The operation lasts from one to two hours in a hermetic chamber where technical sulfur powder is burned in a ratio of $<1 \mathrm{~g}$ per kilogram of prepared fruit. The length of exposure depends on the stage of maturity. The cut apple is immersed in a solution of water and ascorbic acid at a concentration of $0.5 \%$ for 3 minutes. American blueberries and raspberries have a dark pericarp color that is not susceptible to intense oxidation as in the other fruit species analyzed, so they are not treated (Pavkov et al., 2017).

Figure 1. Technological scheme for fruit drying
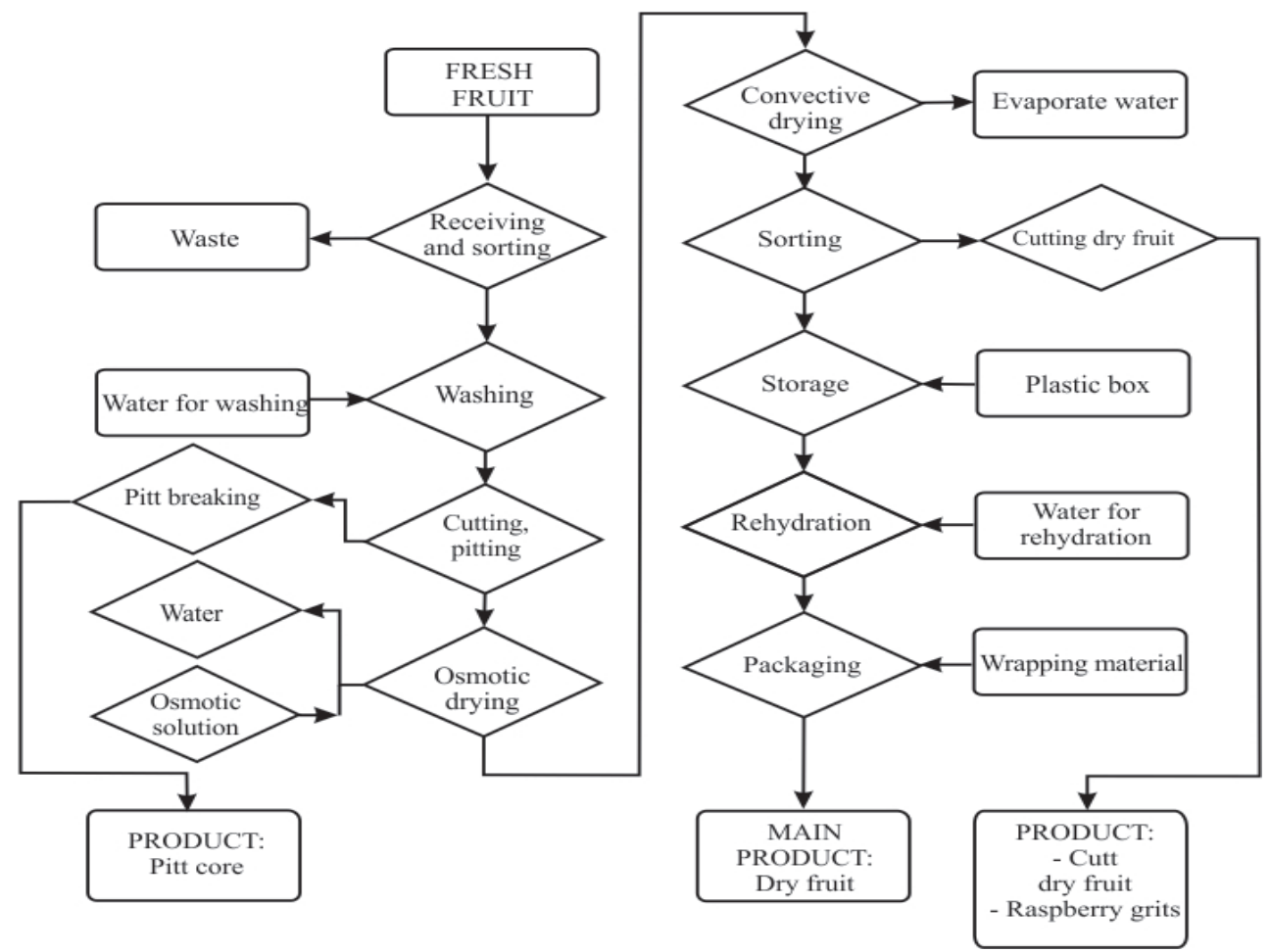

Source: Authors

The fruit prepared according to mentioned procedure is ready for drying. A favorable influence on the quality of the final product in apricot, peach, pear, quince and apples has an osmotic drying (İspir, Toğrul, 2009, Sette et al., 2016). By submerging prepared fruit into concentrated sugar and water concentrations at a concentration of 50-65\% at a temperature of $50^{\circ} \mathrm{C}$, the effect of osmotic pressure is produced, which causes the transition of water from the fruit to the solution (drying) and the transition of the http://ea.bg.ac.rs 
solvent to the surface parts of the fruit. The intensity of this exchange is conditioned by the concentration and temperature of the solution, as well as the exposure time. Various sugars, sucrose (crystal sugar), glucose fructose syrup, sorbitol, mannitol, etc. are used for the osmotic solution. In this paper, fructose syrup was used at a concentration of $60 \%$ at a temperature of $50^{\circ} \mathrm{C}$ and the duration of the osmotic drying was $1 \mathrm{~h}$. During osmotic drying, the average humidity reduction is $7 \%$, with a dry matter increase of $3.5 \%$ compared to the initial values of the prepared fruit. This procedure produces the effect of mild sweetening, as well as the repair of a sweet-sour relation, which significantly affects the sensory properties of the end product. In addition, dry matter that has escaped from the solution into fruit influences the reduction of aw-value, a positive impact on the storage properties of dry fruit. Osmotic drying is not applied to raspberry and American blueberries.

After osmotic drying, the fruit is transferred to convection dryer where the air is heated at $65^{\circ} \mathrm{C}$ temperature. The duration of drying depends on a large number of factors (air temperature for drying, air velocities within the chamber, fruit size, maturity stages, etc.). Within this work, drying time for all fruit species is $12 \mathrm{~h}$. During this time, apricot, peach, pear and quince are dried to a humidity of $24 \%$ which is safe for storage. The American blueberry is dried to $20 \%$ and raspberry to $6 \%$. Usually raspberries are dried by freezing (lyophilization), which is the best way of drying. However, investments in such plants are very significant. An alternative is drying with heated air where a product of lower quality is obtained (darker colors, smaller dimensions, reduced c-vitamin content due to decomposition), but still interesting to the end customer. Within this paper, raspberries are dried by air (Pavkov et al., 2017, Bon et al., 2007).

After drying, selection of dried fruit is done. Fruit that is not sufficiently dried, inadequate in color, with visible dark spots is distinguished and then it is cut into dice that will be used as a supplement (muesli, fruit blocks, confectionery products). With raspberries, the damaged fruits are separated and semolina is made from dried raspberries. Selected dry fruit is packed in plastic boxes and placed in a storage room with controlled temperature and moisture $\left(<18^{\circ} \mathrm{C},<60 \%\right)$. American blueberries are sip into the water solution and fructose syrup concentration of $5 \%$ at a temperature of $70^{\circ} \mathrm{C}$ for 3 minutes (rehydration) before sale packaging.

The analysis of the profitability of future business starts from the estimated market potentials and investment value. According to the research by Vukoje and Milić (2011), the raising of the dryer on the agricultural holding requires an investment of $31,900 €$, revised to 2017 . It is assumed that there is already a part of the facilities and infrastructure that can be adapted and used on the farm.

The calculation of costs and results started from the mass balance of certain types of fruit, which are the result of experimental research and experience norms from practice (Table 1.). Based on daily balances, calculations were made for the estimated number of days of drying each type of fruit. For most products, two main products appear: (a) dry fruits I - represent dry quarters/halves (apricot, peach, pear, apple and quince) or dried fruit (raspberries and 
blueberries), and (b) dry fruit II - which occurs in the form of dry cubes, with the exception of raspberry, which is a dry bite. The side product appears only in apricot, in the form of a dry core used in the confectionery industry and has a significant value.

Within the "waste" position, all types of waste that occur in the process of preparing drying fruits (poor quality fruits, stones, house seeds, etc.) are included. There is a possibility that one of the abovementioned waste is used, for example, for making brandy, feeding the livestock, etc., but this has not been taken into account in this paper, since it is relatively small and uncertain benefits.

Table 1. Mass balances of drying of certain types of fruit $(\mathrm{kg} / \mathrm{day})$

\begin{tabular}{|l|r|r|r|r|r|r|r|r|}
\hline Products & Apricot & Peach & Pear & Apple & Quince & Raspberry & Blueberry & TOTAL \\
\hline Dried fruit I & 75.0 & 75.0 & 95.0 & 75.0 & 90.0 & 50.0 & 70.0 & 530 \\
\hline Dried fruit II & 10.0 & 10.0 & 15.0 & 10.0 & 10.0 & 10.0 & 0.0 & 65.0 \\
\hline Side product & 3.9 & 0.0 & 0.0 & 0.0 & 0.0 & 0.0 & 0.0 & 3.9 \\
\hline Waste & 42.4 & 50.0 & 40.0 & 60.0 & 65.0 & 0.0 & 0.0 & 257 \\
\hline Evaporated water & 368.8 & 365.0 & 350.0 & 355.0 & 335.0 & 440.0 & 430.0 & 2,644 \\
\hline Fresh fruit ( $\boldsymbol{\Sigma}$ ) & $\mathbf{5 0 0}$ & $\mathbf{5 0 0}$ & $\mathbf{5 0 0}$ & $\mathbf{5 0 0}$ & $\mathbf{5 0 0}$ & $\mathbf{5 0 0}$ & $\mathbf{5 0 0}$ & $\mathbf{3 . 5 0 0}$ \\
\hline $\begin{array}{l}\text { Number of drying } \\
\text { days }\end{array}$ & 20 & 30 & 30 & 10 & 10 & 10 & 10 & 120 \\
\hline Total fresh fruit & 10,000 & 15,000 & 15,000 & 5,000 & 5,000 & 5,000 & 5,000 & 60,000 \\
\hline Total dry fruit & 1,700 & 2,550 & 3,300 & 850 & 1,000 & 600 & 700 & 10,700 \\
\hline
\end{tabular}

Source: Authors' calculations

The results of the research have shown that in the structure of the total cost of dried fruit production, fresh fruit dominates, as a basic raw material, on average with $67.1 \%$ (Table 2, Figure 2.). However, there are significant differences between individual production (51.9\% in apples, up to $82.8 \%$ in raspberries and $83.5 \%$ in blueberries), which is primarily due to differences in the price of fresh fruit. Such large variations in the participation of fresh fruit (as a convincingly most significant cost) results in significant ranges in the relative share of other costs in certain production (work, energy, other materials and fixed costs). This may lead to incorrect conclusions on the structure of total costs, since the amount of these costs is very close to the unit of capacity for all observed production (one day of drying, or one kilogram of processed fresh fruit).

Labor costs were also relatively significant (averaging 14.0\%), which, among other things, can be explained by the relatively low automation of technological processes, special in the first stage of "fodder preparation" for drying. Of the "other materials" the most important are the packaging costs (average 6.8\%), the amount of which depends on the quantity of finished products and the size of the packaging. Products with a higher share of dry fruits in the mass balance (apricot, peach, pear, apple and quince) are packed mainly in larger packages (200-400 g), and raspberries and blueberries into smaller packages (50-200 g), with mixes that contain different types of fruits. 
The total energy costs (thermal and electrical combined) were relatively low and make up, on average, about $2.74 \%$ of the total cost. The heat demand for fruit drying depends on the physical and thermophysical properties of dried fruits and the technical characteristics of the dryer. In this case, it is a wood dryer in which the

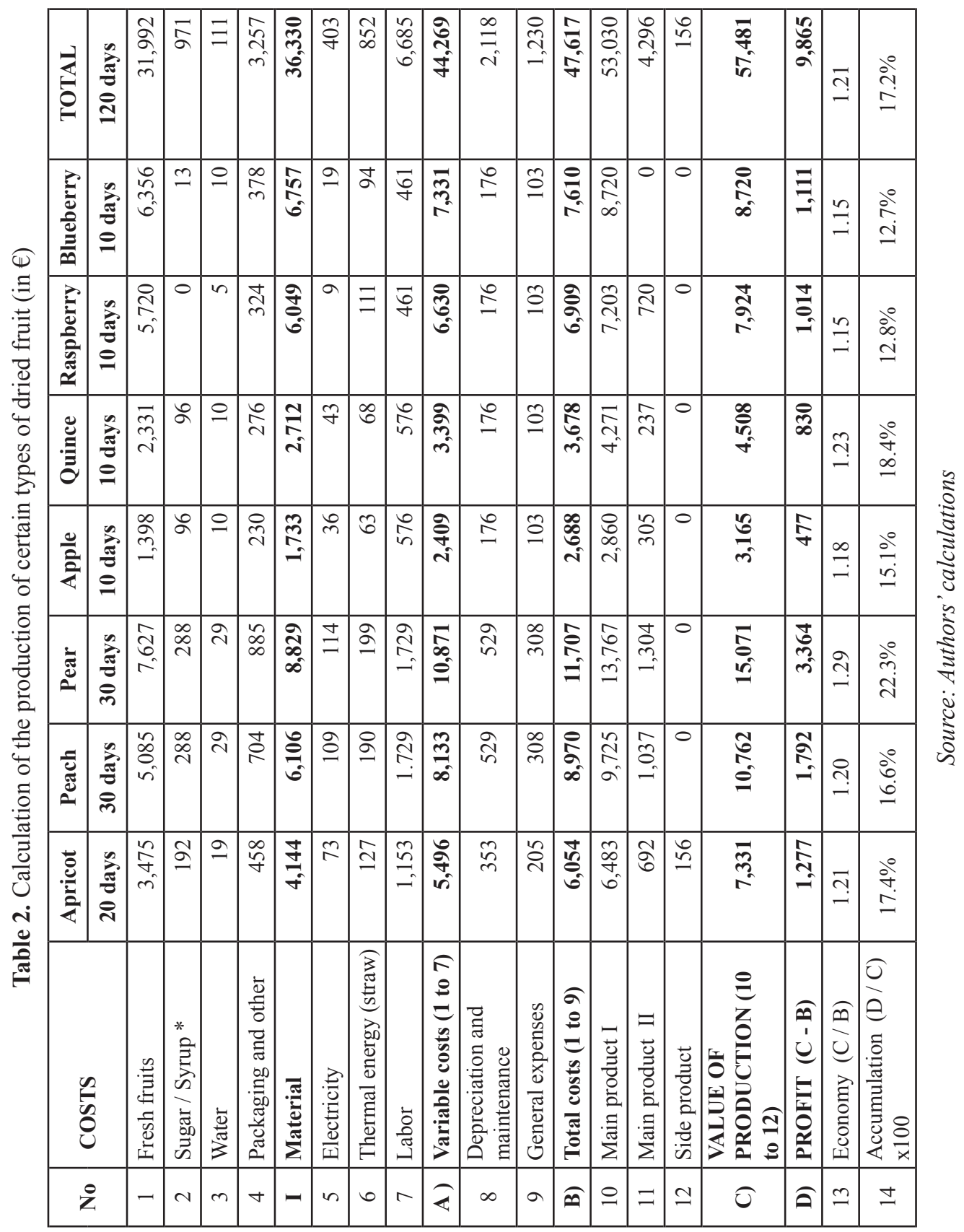


convective drying phase is carried out, characterized by a specific heat consumption of about $\mathrm{q}=6000 \mathrm{~kJ} / \mathrm{kg}$ of water that needs to be brought to dry the fruit. As a fuel for combustion, wheat straw is used for the mean values of lower heat output $\mathrm{Hd}=13,000$ $\mathrm{kJ} / \mathrm{kg}$. Electricity is used for the operation of pumps, fans, heaters for osmotic drying and lighting. The average constant power input is about $2 \mathrm{~kW}$ for 24 hours.

Figure 2. Structure of the cost of production of dried fruit (in \%)

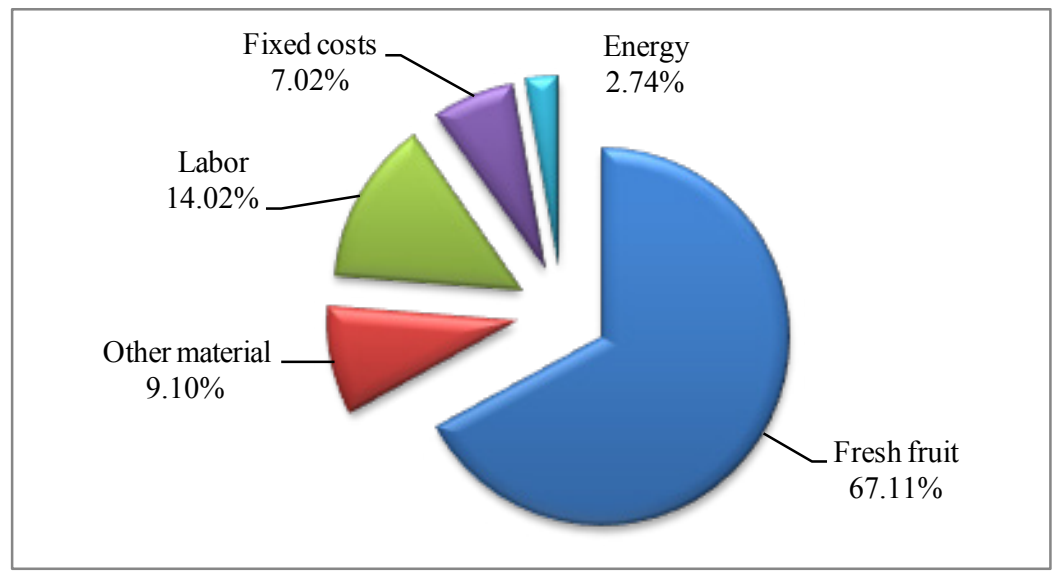

Source: Authors' calculations

The reasons for this modest share of energy costs $(2.74 \%)$ are found in the relatively low electricity price in Serbia, as well as the use of straw for obtaining thermal energy, which is considerably cheaper than other fuels. Contrary to popularity, once again it is confirmed that energy costs are not crucial for the cost-effectiveness of dried fruit production. There is also a question of justification of the replacement of straw with natural gas, which is technically and organizationally considerably more favorable fuel. The equivalent quantity of natural gas is $8.696 \mathrm{~m}^{3}$ for 120 days of drying operation, which at an average price of $48.3 \mathrm{din} / \mathrm{m}^{3}$ amounts to $3,560 €$ in 120 days. With the use of gas instead of straw, energy costs increase by 2,708 $€$ annually and reach a relatively significant share in total costs of $7.97 \%$. The profit is reduced by a significant $27.6 \%$, which seriously brings into question the cost-effectiveness of dried fruit production. On the other hand, the possible increase in electricity prices, which can reasonably be expected in the upcoming period, does not significantly affect the costeffectiveness of production, given the low consumption of this energy ( $0.95 \%$ of total costs).

Fixed costs accounted for $7.02 \%$ of total costs, which represents a relatively significant percentage. Of this, $4.44 \%$ refers to depreciation and amortization, and $2.58 \%$ to the general expenses of the holding. General costs generally include overheads of the farm (telephone, fuel and travel expenses, insurance, taxes and contributions, administrative services, eventual sales costs, etc.). Fixed costs are determined on an annual basis and then allocated to individual production in proportion to the number of days of drying, or used capacity. Since this is a linear distribution of fixed costs, there is no significant difference in the margins of coverage and profit. 
The highest costs per unit of capacity (one day of drying) was required by the production of american blueberries $(761.20 €)$ and raspberries $(691.05 €)$, while the lowest investments in apple production $(269.29 €)$ and peaches $(299.46 €)$. Such large differences are due, above all, to the already mentioned differences in the prices of fresh fruit, since the other costs are very close to the unit of capacity. If we add significant differences in mass balance, then large variations in the price of finished products with a range of up to 3.6 times (raspberry $11.52 € / \mathrm{kg}$, blueberry $10.87 € / \mathrm{kg}$, quince $3.68 € / \mathrm{kg}$, pear $3.55 € / \mathrm{kg}$, peach $3.52 € / \mathrm{kg}$, apricot $3.47 € / \mathrm{kg}$ and apple $3.17 € / \mathrm{kg}$ ) do not surprise. On the basis of the total annual costs and the total amount of dry fruit, the average cost of the main products was $4.44 € / \mathrm{kg}$, which in this case represents only the calculated size.

The average wholesale price of dry fruit amountes to $5.36 € / \mathrm{kg}$, along with large differences between the highest blueberries $(12.46 € / \mathrm{kg})$ and the lowest apple $(3.72 € /$ $\mathrm{kg})$. When VAT is calculated $(20 \%)$ and the average trade margin $(15 \%)$ retail prices for dried fruit is calculated (raspberries $18.22 € / \mathrm{kg}$, blueberry $17.19 € / \mathrm{kg}$, pear 6.30 $€ / \mathrm{kg}$, quince $6.22 € / \mathrm{kg}$, peach and apricot $5.82 € / \mathrm{kg}$ and apple $5.14 € / \mathrm{kg}$ ), which are very competitive on the domestic and foreign market, especially when considering the relation of price and quality. Various mixes of different types of fruit are often packaged together, for which the average selling prices are determined.

The highest production value per unit of capacity (working day) was realized in the production of blueberries (872.4 $€$ ) and raspberries (792.0 $€$ ), and the lowest in apple $(316.5 €)$ and peach production $(358.7 €)$. The order is practically the same as for the total cost. However, the highest profit per unit of capacity is achieved in pear production $(111.7 €)$, followed by blueberries $(110.8 €)$ and raspberries $(101.3 €)$, while apple $(872.4 €)$ and peach are least profitable $(872.4 €)$ (Figure 3.).

Figure 3. Economics and profit per unit of capacity (€/day)

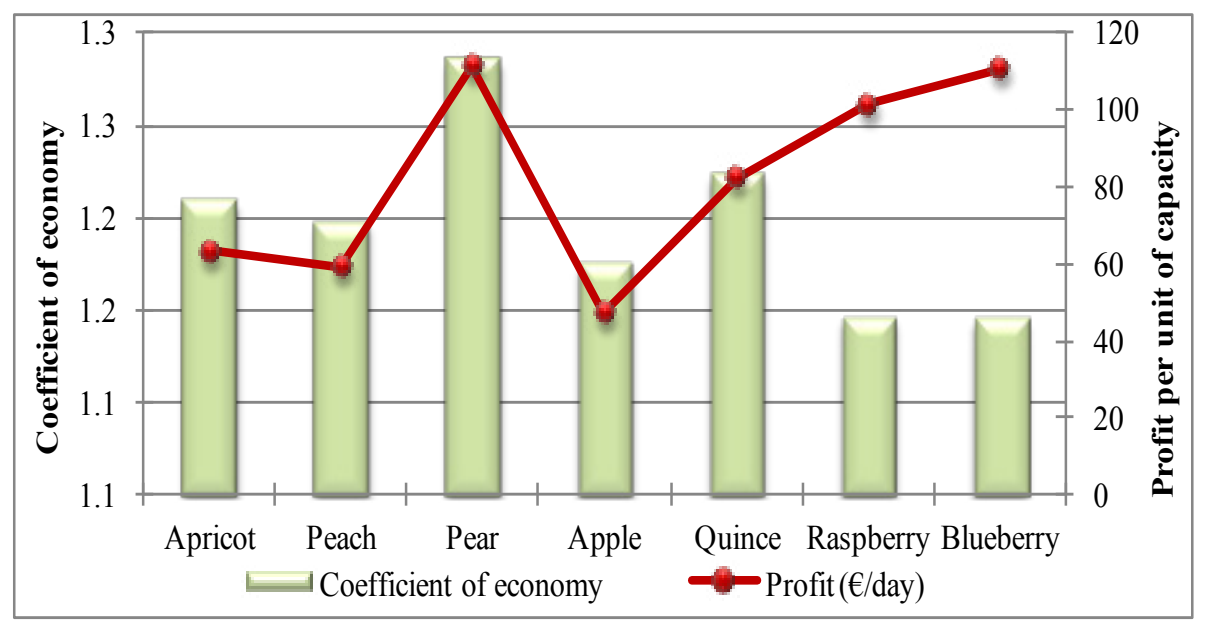

Source: Authors' calculations 
According to the criterion of economy, the most favorable relation between production and cost is also achieved in pear production (1.29), followed by quince (1.22) and apricot (1.21), while blueberries and raspberries (1.15) are the worst. The same sequence shows the profitability indicator of production, which is logical, since it is a similar type of indicator (Table 2, Figure 3.).

We see that the two basic criteria (profit per unit of capacity and economy) show a very different order of profitability for observed production. The question which criterion to prioritize arises? The answer to this question, in each specific case, requires deeper analysis with the inclusion of additional criteria (market, production, organizational, financial). Generally speaking, one should take into account what is the key limiting factor of maximizing the overall profit of the dryer. If the financial resources available to the household are, then the most important is the economy, because one RSD of investment earns the highest salary. In contrast, if the farm does not have restrictions on financing the production, but it is the effective capacity of the dryer during the year, priority should be given to those products that reject the highest earnings per day of the operation of the dryer, as the overall profit will be the highest.

The total annual profit of dryers, ie 120 days of effective work was 9,815 € (Table 2.). This can be considered a good income, especially if it is a supplementary activity in the agricultural holding. The coefficient of economy (1.21) and the production accumulation rate $(17.1 \%)$ are also at a satisfactory level. If two members of the household are employed (out of a total of 5 required workers), earnings can be expressed in the form of "income" of the farm, which amounts to $12,488 €$.

In addition to a comparative analysis of the profitability of drying certain types of fruits, that is, the annual net yield of dryers, it is important to consider the justification of the total investment project for the construction of a plant for drying fruits in the agricultural holding. The most important indicator of the return on investment is the return on investment (Table 3.). In this case, the funds invested are returned for 2.74 years, which is a relatively short repayment period, especially for this type of investment. The rate of return on investment is at a high level (30.8\%), bearing in mind that it exceeds the average values of interest rates in several ways.

Table 3. Basic indicators of cost-effectiveness of the investment (in $€$ )

\begin{tabular}{|c|l|r|}
\hline No & \multicolumn{1}{|c|}{ TYPE OF INDICATOR } & \multicolumn{1}{c|}{$\boldsymbol{\epsilon} /$ year } \\
\hline 1 & Total profit & 9,815 \\
\hline 2 & Depreciation on annual basis & 1,818 \\
\hline 3 & Financial flow (1+2) & 31,632 \\
\hline 4 & Total investment value $(€)$ & $\mathbf{2 . 7 4}$ \\
\hline 5 & Time of return on investment $(4 / 3)$ & $\mathbf{3 0 . 8 \%}$ \\
\hline 6 & Profitability of the investment $(1 / 4)$ & \\
\hline
\end{tabular}

Source: Authors' calculations 
Sensitive analysis in this case has a limited value, since it is based on the average prices of the observed types of fresh and dried fruit. The net financial result becomes negative with the increase in the average market price of fresh fruit by $31 \%$. Profitability is considerably more sensitive to the decrease in the average selling price of finished products, and already with $17 \%$ decrease drier is in loss.

\section{Conclusion}

The results of the study show that the drying of the analyzed fruit species represents costeffective production in the described conditions. This proved the established hypothesis of research. Medium capacity drier for 120 days of effective production yields a profit of $9,815 €$, with an acceptable coefficient of economy (1.21) and production accumulation $(17.1 \%)$. An additional benefit for the household can be achieved by hiring family members in the fruit drying process. There are significant differences in the level of profitability of drying of certain types of fruit, which mainly arise from the differences in prices of fresh fruit, which is a key factor for the profitability of this production. The partial use of fresh fruit from its own production significantly reduces costs and increases the profitability of dryers.

The construction of a plant for drying fruits on a family farm does not require large investment $(31,900 €)$, which are repaid in 2.74 years. It is obvious that this is a viable business venture, which can be a good source of income for agricultural holdings. The development of small and medium-sized enterprises in agriculture can be largely achieved in the domain of fruit drying. The Republic of Serbia has great chances for increasing the export of dry fruit, bearing in mind the constant increase of consumption of this product in the world.

\section{Acknowledgements}

Paper is a part of research within the project no. TR31058 by the Ministry of Education, Science and Technological Development and the project "Analysis of production and economic results of business entities in the field of agriculture and food industry of AP Vojvodina", financed by the Provincial Secretariat for Science and Technological Development APV.

\section{Conflict of interests}

The authors declare no conflict of interest.

\section{References}

1. Bon, J., Rossello, C., Femenia, A., Eim, V., \& Simal, S. (2007). Mathematical modeling of drying kinetics for apricots: Influence of the external resistance to mass transfer. Drying Technology, 25(11), 1829-1835. https://doi.org/ 10.1080/07373930701677918.

2. INC International Nut and Dried Fruit Council (2018). Nuts \& dried fruits, Statistical yearbook, 2017/2018, Spain, Retrieved from https://www.nutfruit.org/ industry/ technical-resources?category=statistical-yearbooks (July, 2018). 
3. İspir, A., \& Toğrul, İ. T. (2009). Osmotic dehydration of apricot: Kinetics and the effect of process parameters. Chemical Engineering Research and Design, 87 (2), 166-180. https://doi.org/10.1016/j.cherd.2008.07.011

4. Lukač Bulatović, M., Rajić, Z., \& Ljubanović Ralević, I. (2012). Economic features of processed fruit production in Serbia. Economics of Agriculture, 59(4), 715-725.

5. Lukač, M., Vukoje, V., \& Milić, D. (2017). Economic indicators of the production of important fruit-specific species in Vojvodina. Economics of agriculture, 64(3), 973-986.

6. Milić, D., Vukoje, V., \& Sredojević, Z. (2010). Production characteristics and economic aspects of quince production. PTEP, vol. 14, no. 1, p. 36-39.

7. Pavkov I., Babić Lj., Babić M., \& Radojčin M. (2009). Kinetics of the combined drying technology of pear slices (Pyrus). Jounal on Processing and Energy in Agriculture (PTEP), 13(2), 111-116.

8. Pavkov I., Babić M., Babić Lj., Radojčin M., \& Stojanović Č. (2011). Effects of Osmotic Pre-Treatment on Convective Drying Kinetics of Nectarines Halfes. Jounal on Processing and Energy in Agriculture, vol. 15(4), 217-221.

9. Pavkov I., Babić M., Babić Lj., Radojčin M., \& Stojanović Č. (2010). Effects of Osmotic Dehydration Factors on Convective Drying Kinetics of Pears Slices. Jounal on Processing and Energy in Agriculture, 14(3), 125-130.

10. Pavkov, I., Babić, M., Radojčin, M., Stamenković, Z., Bikić, S., \& Bukurov, M. (2016). Effect of the Osmotic Pre-treatment on the Convective Air Drying Kinetics of Apricot. III Intenational CongressFood Technology Quality and Safety, Novi Sad, Serbia, Proceedings, ISBN 978-86-7994-050-6, 607-611.

11. Pavkov, I., Stamenković, Z., Radojčin, M., Babić, M., Bikić, S., \& Mitrevski, V., Lutovski, M. (2017). Convective and Freeze Drying of Raspberry: Effect of Experimental Parameters on Drying Kinetics, Physical Properties and Rehydration Capacit. Proceedings of Fifth Intenational Conference Sustainable Postharvest and Food Technologies- 2017, ISBN 978-86-7520-393-3, Vršac, 261-267.

12. Radojčin M., Babić M., Babić Ljiljana, \& Pavkov I. (2010). Color parameters change of quince during combined drying. Jounal on Processing and Energy in Agriculture, 14(2), 81-84.

13. Radojčin, M., Babić, M., Babić, Lj, Pavkov, I., Bukurov, M., Bikić, S., \& Mitrevski, V. (2015). Effects of osmotic pretreatment on quality and physical properties of dried quinces, Journal of food and nutrition research. 54(2), 142-154.

14. Sette, P., Salvatori, D., \& Schebor C. (2016). Physical and mechanical properties of raspberries subjected to osmotic dehydration and further dehydration by air and freeze-drying. Food and Bioproducts Processing. 100 (1), 156-171. https://doi. org/10.1016/j.fbp.2016.06.018 
15. Statistical Office of the Republic of Serbia, Statistical database „Export and Import", (2017). Retrieved from http://data. stat.gov.rs/ Home/Result/ 170304?languageCode=sr-Cyrl (Jun, 2018).

16. Vukoje, V, Jasmina, Živković, Zekić, V., \& Matković, M. (2013). Economic effects of dried sour cherry production in Serbia. Proceedings of the IV International Agronomic Symposium „Agrosym 2013“, Jahorina, Bosnia and Herzegovina, 792-795.

17. Vukoje, V., \& Pavkov, I. (2010). Analysis of economic justification of drying of apricots by combined tehnology. Journal on Processing and Energy in Agriculture (PTEP), 14(1), 36-39.

18. Vukoje, V., \& Milić, D. (2011). Analysis of the economic feasibility of dried fruit production in Serbia. Agroznanje, 12(1), 5-14. [in Serbian: Vukoje, V., Milić, D. (2011), Analiza ekonomske opravdanosti proizvodnje sušenog voća u Srbiji].

19. Vukoje, V., \& Pavkov, I. (2015). Profitability of dired apple production in Serbia. Contemporary Agriculture, 64(3-4), 143-149.

20. Vukoje, V., Milić, D., \& Pavkov, I. (2011). Production-Economic Parameters of Dried Quince. Proceedings of the XXII Internacional Symposium Food safety production, Poljoprivredni fakultet, Novi Sad, 227-230.

21. Vukoje, V., Pavkov, I., \& Babić, M. (2010). Economic Effects Of Dried Pear Production Using Combined Technology. Economics of agriculture, 57(Special issue 2), 219-227.

22. Vukoje, V., Radojčin, M., \& Dulić, V. (2017). Cost-effectiveness assessment of dried raspberry production. Journal on Processing and Energy in Agriculture, 21(1), 50-52. 